\title{
Effects of coconut shell ash on lime-stabilized lateritic soil
}

\begin{abstract}
This study assesses the effects of Coconut Shell Ash (CSA) on lime-stabilized lateritic soil. Preliminary tests were carried out on the natural soil sample for identification and classification purposes, also, engineering property tests such as California Bearing Ratio (CBR), Unconfined Compressive Strength (UCS) and Compaction were carried out on the natural soil sample. Lime being the main stabilizing material was thoroughly mixed with the natural soil sample in proportions of 2, 4, 6, 8 and $10 \%$. The optimum lime requirement for stabilization was $6 \%$ lime content because the least value of plasticity index was recorded at this level. This value was adopted as the standard and control, thereafter, CSA was mixed with the lime-stabilized soil in proportions of 2, $4,6,8$ and $10 \%$. By the addition of CSA to the lime-stabilized soil, CBR increased from $53.6 \%$ at $0 \%$ CSA to $66.4 \%$ at $6 \%$ CSA. UCS increased from $345 \mathrm{kN} / \mathrm{m}^{2}$ at $0 \%$ CSA to highest value of $442 \mathrm{kN} / \mathrm{m}^{2}$ at $4 \%$ CSA by weight of soil. Values of Optimum Moisture Content (OMC) increased from $21.44 \%$ at $0 \%$ CSA to $26.10 \%$ at $10 \%$ CSA. Maximum Dry Density (MDD) decreased from $1342 \mathrm{Kg} / \mathrm{m}^{3}$ at $0 \% \mathrm{CSA}$ to $1255 \mathrm{Kg} / \mathrm{m}^{3}$ at $10 \%$ CSA. It was therefore concluded that Coconut Shell Ash (CSA) is an effective complement for lime stabilization in lateritic soil.
\end{abstract}

Keywords: atterberg limits, coconut shell ash, engineering property tests, geotechnical properties, lateritic soil, lime stabilization
Volume 2 Issue 4 - 2017

\author{
Nnochiri Emeka Segun,' Emeka Helen \\ Oluyemisi ${ }^{2}$ \\ 'Department of Civil Engineering, Afe Babalola University, \\ Nigeria \\ ${ }^{2}$ Department of Mathematical and Physical Sciences, Afe \\ Babalola University, Nigeria
}

\begin{abstract}
Correspondence: Nnochiri, Emeka Segun, Department of Civil Engineering, Afe Babalola University, Ado-Ekiti, Nigeria, Tel +2348061378929, Email segunemeka@yahoo.com
\end{abstract}

Received: December 18, 2017| Published: April 24, 2017

\section{Introduction}

Lateritic soils are the products of intensive weathering that occurs under tropical and subtropical climatic conditions resulting in the accumulation of the hydrated iron and aluminum oxides. ${ }^{1}$ Some lateritic soils in their natural states generally have low bearing capacity and low strength due to high content of clay. When lateritic soil contains a large amount of clay minerals its strength and stability cannot be guaranteed under load especially in the presence of moisture. When lateritic soil consists of high plastic clay, the plasticity of the soil may cause cracks damage on pavement, road ways, building foundations or any civil engineering construction projects. This improvement in the strength and durability of lateritic soil in the recent time has become imperative, this, has encouraged researchers toward using stabilizing materials that can be sourced locally at a very low cost. These local materials can be classified as either agricultural or industrial wastes. ${ }^{2}$

According to Patel, ${ }^{3}$ soil stabilization is a process of treating a soil to maintain, alter or improve the performance of the soil as a construction material. Ogundipe ${ }^{4}$ defines stabilization as the process of blending and mixing materials with a soil to improve certain properties of the soil. The process may include the blending of soils to achieve the desired graduation and or the mixing of commercially available additives that may alter the graduation, texture or plasticity or cut as a blender for cementation of the soil.

\section{Lime stabilization}

Lime is the oldest traditional chemical stabilizer used for soil stabilization. Lime-soil chemical reaction has two stages. The first stage, which is known as immediate or short-term treatment, occurs with a few hours or days after lime is added. Three main chemical reactions namely, cation exchange, flocculation-agglomeration and carbonation occur at this stage. The second stage requires several months and years to complete and is thus considered the long-term treatment. Pozzolanic reaction is the main reaction at this stage. The drying of wet soil and the increase of soil workability is attributed to the immediate treatment, whereas the increase in soil strength and durability is associated with the long-term treatment. The reaction between the released soluble silica and aluminum and the calcium ions from lime hydration creates cementitious materials such as Calcium Silicate Hydrates (C-S-H) and Calcium Aluminum Hydrates $(\mathrm{C}-\mathrm{A}-\mathrm{H}){ }^{5}$

\section{Coconut}

Coconut has its scientific name as Cocos nucifera. Early Spanish explorers called it coco, which means 'monkey face' because the three indententations (eyes) on the hairy nut resembles the head and face of a monkey. Nucifera means 'nut-bearing'. Coconut palm trees grow abundantly along the coastline of countries within $15^{\circ}$ of the equator. They prosper in sandy, saline soil and in tropical climates. A healthy coconut tree will produce approximately 120 watermelonsized husks per year, each with a coconut imbedded inside. There are three components of the Cocos nucifera that can be used for fuel: the husk, the coconut shell and the coconut oil that is in the white coconut 'meat' or copra as it is normally called. In light of the foregoing, the coconut tree is a very abundant, renewable resource of energy. When coconuts are harvested, the husks are removed, thereby leaving the shell and the copra. Large quantities of the shells can be obtained in places where coconut meat is used for food processing. Both the shells and the husks are regarded as waste materials. These materials are burnt into ashes in a furnace at a very high temperature to produce the coconut shell and husk ash. ${ }^{6}$ 


\section{Materials and method}

\section{Materials}

This research was conducted at the Geotechnical Laboratory of the Federal University of Technology, Akure. The materials used were Lateritic soil, Lime, Coconut Shell Ash (CSA), and Portable water. The lateritic soil sample was obtained from an existing burrow pit within the campus of Federal University of Technology, Akure, Nigeria at a depth not less than $1.2 \mathrm{~m}$. The lime was purchased from a licensed Chemical store?

Coconut shells were obtained from the store of a local coconut oil ointment dealer in Akure. The shells were well dried to eliminate moisture and burnt in the open air till it turned to ash. The burnt ash was ground and seived through a BS Sieve (75microns) to get the required fine ash. Portable water was obtained from treated in the laboratory. The soil sample was kept in the sack and left in the laboratory to enable the samples to be properly air-dried for a minimum of two weeks. The sample was kept away from water and sunlight contacts during the drying process and even drying of the soil sample was ensured.

\section{Method}

Preliminary tests (such as Natural moisture content, specific gravity, particle size distribution and Atterberg limit tests) were carried out on the soil sample for classification and identification purposes. Lime which was the main stabilizing material was thoroughly mixed with soil sample in varying proportions of $2,4,6,8$ and $10 \%$ by weight of the soil sample Table 1. The geotechnical properties of the lime-stabilized soil were thereafter determined. These said properties were employed as the standard and control to evaluate the effects of CSA on the lime stabilized soil. The summary of the preliminary test results for the soil sample is shown in Table 2. The natural moisture content of the soil sample is 13.6. According to Amu \& Babajide. ${ }^{8}$ Moisture content of a soil depends on the void ratio. The specific gravity of the sample is 2.36. Classification of the soil according to Amadi et al., ${ }^{9}$ stipulates that for a soil sample to be classified as A-7-6, the percentage passing BS No 200 sieve must be more than $35 \%$, for this soils sample, it is $55 \%$. The minimum value for liquid limit for the A-7-6 category is $40 \%$, the soil sample has a liquid limit of $49.4 \%$. According to Garber \& Hoel, ${ }^{10}$ plasticity index of A-7-6 subgroup > LL-30, therefore, $36.1>19.4$. From the foregoing, the soil rightly belongs to the A-7-6 subgroup.

Table I Chemical composition of coconut shell ash (CSA) ${ }^{7}$

\begin{tabular}{ll}
\hline Elemental oxide & Weight (\%) \\
\hline $\mathrm{K}_{2} \mathrm{O}$ & 0.83 \\
$\mathrm{Na}_{2} \mathrm{O}$ & 0.95 \\
$\mathrm{CaO}$ & 4.98 \\
$\mathrm{MgO}$ & 1.89 \\
$\mathrm{Al}_{2} \mathrm{O}_{3}$ & 24.12 \\
$\mathrm{P}_{2} \mathrm{O}_{5}$ & 0.32 \\
$\mathrm{SO}_{3}$ & 0.71 \\
$\mathrm{SiO}_{2}$ & 37.97 \\
$\mathrm{Fe}_{2} \mathrm{O}_{3}$ & 15.48 \\
$\mathrm{MnO}$ & 0.81 \\
$\mathrm{LOI}$ & 11.94 \\
\hline
\end{tabular}

Table 2 Summary of preliminary and engineering properties of soil sample

\begin{tabular}{ll}
\hline Property & Values \\
\hline Percentages passing BS No 200 sieve (\%) & 55 \\
Natural Moisture Content & 13.6 \\
Specific gravity & 2.36 \\
AASHTO classification & A-7-6 \\
Liquid limit (\%) & 49.4 \\
Plastic limit & 13.3 \\
Plasticity Index (\%) & 36.1 \\
Maximum Dry Density (kg/m $\left.{ }^{3}\right)$ & 1398 \\
Optimum Moisture Content (\%) & 17.42 \\
California Bearing Ratio (\%) & 7.9 \\
Unconfined Compressive Strength (UCS) & 275 \\
\hline
\end{tabular}

\section{Engineering tests}

From Table 3, the optimum lime percentage for stabilization was $6 \%$. This optimum value was employed to determine the engineering properties of the stabilized samples before adding CSA. It was also observed that the plasticity index of the soil reduced, this reduction is an indication of soil improvement. ${ }^{11}$

Table 3 Result for Atterberg's limit for the lime stabilization

\begin{tabular}{llll}
\hline \% Lime by weight & LL (\%) & PL (\%) & PI (\%) \\
\hline 0 & 49.5 & 28.1 & 21.4 \\
2 & 46.4 & 29.2 & 17.2 \\
4 & 45.7 & 29.9 & 15.8 \\
6 & 44.2 & 30.5 & 13.7 \\
8 & 43.6 & 28 & 15.6 \\
10 & 42.7 & 26.7 & 16 \\
\hline
\end{tabular}

From Table 4, with the increasing addition of lime to soil, values of MDD reduced from $1398 \mathrm{~kg} / \mathrm{m}^{3}$ at $0 \%$ to $1302 \mathrm{~kg} / \mathrm{m}^{3}$ at $10 \%$ and OMC values increased from $17.42 \%$ at $0 \%$ CSA to $22.95 \%$ at $10 \%$ CSA. Decrease in MDD values may be attributed to the coating of the soil by the lime which result to large particles with larger voids and hence less density. While increase in values of OMC may be due to the addition of lime which decreases the quality of free silt and clay fraction and coarser materials with larger surface area were formed, these processes need water to take place. This implies also that more water is needed in order to compact the Soil-lime mixtures. ${ }^{12}$ From Table 5, values of UCS increased from $275 \mathrm{kN} / \mathrm{m}^{2}$ at $0 \%$ lime content to highest value of $365 \mathrm{kN} / \mathrm{m}^{2}$ at $4 \%$ before gradually reducing to $310 \mathrm{kN} /$ $\mathrm{m}^{2}$ at $10 \%$ lime From Table 6, value of CBR and UCS increased from $53.6 \%$ at $0 \%$ CSA to $66.4 \%$ at $6 \% \mathrm{CSA}$ and from $345 \mathrm{kN} / \mathrm{m}^{2}$ to $442 \mathrm{kN} /$ $\mathrm{m}^{2}$ at $4 \%$ CSA respectively before reducing to $63.8 \%$ at $10 \%$ CSA and $395 \mathrm{kN} / \mathrm{m}^{2}$. The increase in CBR may be because of the gradual formation of cementitious compounds in the soil by the reaction between the CSA and some amounts of $\mathrm{CaOH}$ present in the limestabilized soil. 
Table 4 Effects of lime on compaction of soil

\begin{tabular}{lll}
\hline Lime content $(\%)$ & MDD $\left(\mathrm{kg} / \mathrm{m}^{3}\right)$ & OMC $(\%)$ \\
\hline 0 & 1398 & 17.42 \\
2 & 1376 & 18.35 \\
4 & 1360 & 20.12 \\
6 & 1342 & 21.44 \\
8 & 1320 & 22.25 \\
10 & 1302 & 22.95 \\
\hline
\end{tabular}

Table 5 Effects of lime on CBR and UCS of lateritic soil

\begin{tabular}{lll}
\hline Lime content (\%) & UCS $\left(\mathbf{k g} / \mathbf{m}^{2}\right)$ & CBR (\%) \\
\hline 0 & 275 & 7.9 \\
2 & 350 & 28.3 \\
4 & 365 & 41.2 \\
6 & 345 & 53.6 \\
8 & 330 & 51.8 \\
10 & 310 & 50.2 \\
\hline
\end{tabular}

Table 6 Effects of CSA values on CBR and UCS of lime stabilized soil

\begin{tabular}{lll}
\hline CSA content $(\%)$ & CBR $(\%)$ & UCS $\left(\mathbf{k N} / \mathbf{m}^{2}\right)$ \\
\hline 0 & 53.6 & 345 \\
2 & 50.5 & 420 \\
4 & 64.3 & 442 \\
6 & 66.4 & 425 \\
8 & 65.1 & 415 \\
10 & 63.8 & 395
\end{tabular}

The increase in the UCS is attributed to the formation of cementitious compounds between the $\mathrm{CaOH}$ present in the soil and CSA and the pozzolans present in CSA. This decrease in the UCS values after the addition of $6 \%$ CSA may be due to the excess CSA introduced to the lime-stabilized soil and therefore forming weak bonds between the soil and the cementitious compounds formed. The decrease in CBR may be due to extra CSA that could not be mobilized for the reaction which consequently occupies space within the sample. This reduced the bond in the lime-stabilized soil-CSA mixture. ${ }^{12}$

Table 1 shows that with the addition of CSA to lime-stabilized soil, values of OMC increased. Increase in values of OMC may be due to the addition of CSA which decreases the quantity of free silt and clay fraction and coarser materials with larger surface areas were formed, these processes need water to take place. ${ }^{13}$

Table 2 shows that with the addition CSA to the lime-stabilized soil, the values of the MDD decreased. Decrease in the maximum dry unit weight may be explained by considering the CSA as filler (with lower specific gravity) in the soil voids. ${ }^{14}$

\section{Conclusion}

The tests were carried out in accordance with BS $1377^{15}$ and BS
1924. ${ }^{16}$ Addition of Coco-nut Shell Ash (CSA) further increased the CBR and UCS values of the lime-stabilized soils. It can therefore be concluded that the Coco-nut Shell Ash (CSA) is a good complement for lime stabilization in lateritic soils.

\section{Acknowledgements}

The Authors are grateful to Engr. M. Tanimola and the technical crew of the Geotechnical Engineering Laboratory of the Federal University of Technology, Akure, Nigeria, for all the support and cooperation given while this work lasted.

\section{Conflict of interest}

The author declares no conflict of interest.

\section{References}

1. Ugbe FC. Basic Engineering Global Geological Properties OF Lateritic Soils from Western Delta Research. Journal of Environmental and Earth Sciences. 2011;3(5):571-577.

2. Ogunribido THT. Potential of Sugar Cane Straw Ash for Lateritic Soil Stabilization in Road Construction. International Journal Science Emerging Technology. 2012;3(5):5.

3. Patel MA, Patel HS. A Review on Effects of Stabilizing Agents for Stabilization of Weak Soil. Civil and Environmental Research. 2012;2:6.

4. Ogundipe OM. An Investigation into the Use of Lime-Stabilized Clay as Sub grade Material. International Journal of Scientific and Technology Research. 2013;2:10

5. Jawad IT, Taha MR, Majeed ZH, et al. Soil Stabilization Using Lime: Advantages, Disadvantages and Proposing a Potential Alternative. Research Journal of Applied Sciences, Engineering and Technology. 2014;8(4):510-520.

6. Amu OO, Owokade OS, Shitan OI. Potentials of Coconut Shell and Husk Ash on the Geotechnical Properties of Lateritic Soil for Roadworks. International Journal of Engineering and Technology. 2011;3(2):87-94.

7. Utser JT, Taku JK. Coconut Shell Ash as Partial Replacement of OPC in Concrete Production. International Journal of Scientific and Technology Research. 2012;1:8.

8. Amu OO, Babajide SS. Effects of Bamboo Leaf on Lime Stabilized Lateritic Soil for Highway Construction. Research Journal of Applied Sciences, Engineering and Technology. 2011;3(4):278-283.

9. Amadi AN, Akande WG, Okunlola IA, et al. Assessment of the Geotechnical Properties of Lateritic Soils in Minna, North Central Nigeria for Road Design and Construction. American Journal of Mining and Metallurgy. 2015;3(1):15-20.

10. Garber NJ, Hoel LA. Traffic and Highway Engineering. 4th ed. Canada: Cengage Learning; 2009.

11. Bello AA, Ige JA, Hammed A. Stabilization of Lateritic Soil with Cassava Peels Ash. British Journal of Applied Science and Technology. 2015;7(6):642-650.

12. Fattah MY, Rahil FH, Al-Soudany KYH. Improvement of Clayey Soil Characteristics Using rice Husk Ash. Journal of Civil Engineering and Urbanism. 2013;3(1):12-18.

13. Joel M, Edeh JE. Comparative Analysis of Cement and Lime Modification of Ikpayongo Laterites for Effective and Economic Stabilization. Journal of Emerging Trends in Engineering and Applied Sciences (JETEAS). 2015;6(1):49-56.

14. Adetoro AE, Adam JO. Comparative Analyses of Ekiti State Soil stabilized with different Additives. Asian Journal of Science and Technology. 2015;6(12):2054-2058. 
15. British Standards (BS) 1377. Methods of Tests for Soils for Civil Engineering Properties. UK: British Standards Institution; 1990.
16. British Standards (BS) 1924. Methods of Test for Stabilized Soils. UK: British Standards Institutions; 1990. 